NBER WORKING PAPER SERIES

\title{
DOES PREKINDERGARTEN IMPROVE SCHOOL PREPARATION AND PERFORMANCE?
}

Katherine A. Magnuson

Christopher J. Ruhm

Jane Waldfogel

Working Paper 10452

http://www.nber.org/papers/w10452

\author{
NATIONAL BUREAU OF ECONOMIC RESEARCH \\ 1050 Massachusetts Avenue \\ Cambridge, MA 02138 \\ April 2004
}

This research was supported by a grant from the Russell Sage Foundation's Social Inequality program. We are grateful to Eric Wanner and participants at the May 2003 Social Inequality conference for helpful comments. We would also like to thank Marcia Meyers and Dan Rosenbaum for many helpful discussions. Additional funding support was provided by the John D. and Catherine T. MacArthur Foundation, NICHD, and NSF. The views expressed herein are those of the author(s) and not necessarily those of the National Bureau of Economic Research.

(C2004 by Katherine A. Magnusun, Christopher J. Ruhm, and Jane Waldfogel. All rights reserved. Short sections of text, not to exceed two paragraphs, may be quoted without explicit permission provided that full credit, including (C) notice, is given to the source. 
Does Prekindergarten Improve School Preparation and Performance?

Katherine A. Magnusun, Christopher J. Ruhm, and Jane Waldfogel

NBER Working Paper No. 10452

April 2004

JEL No. J13, I20, I28

\section{ABSTRACT}

Prekindergarten programs are expanding rapidly, but to date, evidence on their effects is quite limited. Using rich data from Early Childhood Longitudinal Study, we estimate the effects of prekindergarten on children's school readiness. We find that prekindergarten increases reading and mathematics skills at school entry, but also increases behavioral problems and reduces self-control. Furthermore, the effects of prekindergarten on skills largely dissipate by the spring of first grade, although the behavioral effects do not. Finally, effects differ depending on children's family background and subsequent schooling, with the largest and most lasting academic gains for disadvantaged children and those attending schools with low levels of academic instruction.

Katherine A. Magnuson

Columbia University School of Social Work

622 W. $113^{\text {th }}$ Street

New York, NY 10025

kam2101@columbia.edu

Christopher J. Ruhm

Department of Economics

University of North Carolina at Greensboro

P.O. Box 26165

Greensboro, NC 27402-6165

c-ruhm@uncg.edu

Jane Waldfogel

Columbia University School of Social Work

622 W. $113^{\text {th }}$ Street

New York, NY 10025

jw205@columbia.edu 


\section{Does Prekindergarten Improve School Preparation and Performance?}

\section{Introduction}

The share of U.S. children attending early education programs has risen dramatically in recent years -- $66 \%$ of four-year olds were enrolled in a center or school-based preschool program in 2001, up from 23\% thirty years earlier (U.S. Bureau of the Census, 1970; US Department of Education, 2003). Particularly striking is the increase in prekindergarten programs, early education programs sponsored by school districts, which now serve one in seven four-year olds (U. S. General Accounting Office, 2000a, 2000b; Gilliam and Zigler, 2001). Expansion of prekindergarten is partly motivated by concerns that many children are insufficiently prepared at the time of school entry, with particularly large academic skill deficits for disadvantaged groups. For example, in 1990, governmental leaders endorsed as the first of eight national educational goals that: "By the year 2000, all children should enter school ready to learn." One of the three objectives under this goal was that all children should have access to high-quality and developmentally appropriate preschool programs that help prepare children for school (Committee for Economic Development, 2002).

Despite these goals, the enrollment of disadvantaged children in early education programs remains relatively low. Children whose mothers did not complete high school are half as likely to be in center-based care arrangements as those whose mothers have a college degree (US Department of Education, 2003). Similar gaps exist between children from low and high income families (Bainbridge et al., 2002). To equalize access to high quality early education opportunities, there have been numerous calls for expanded public support of prekindergarten (Bowman, Donovan and Burns, 2001; Committee on Economic Development, 2002; Wolfe and 
Scrivner, 2003). Since 1990, overall state funding for prekindergarten has increased $250 \%$ to approximately $\$ 1.9$ million (Education Week, 2002). In 2000, a total of 39 states had prekindergarten initiatives, although fewer -- Connecticut, Georgia, Illinois, Kentucky, Massachusetts, Ohio, and Oklahoma - had made substantial per capita investments (Schulman et al., 1999; Ripple et al., 1999; Education Week, 2002). ${ }^{1}$ Local school districts also invest in prekindergarten programs independently, although the bulk of this money comes from federal funding streams (Smith et al., 2003).

Evidence of effects of prekindergarten on school readiness and subsequent educational performance is quite limited. We know that model early education programs promote academic skills, but know much less about typical programs. Data are particularly lacking for prekindergarten programs. This paper begins to fill this gap by addressing three specific questions. First, does prekindergarten increase school readiness at kindergarten entry, as assessed by reading and mathematics skills, and behavioral problems? Second, do any effects of prekindergarten attendance at the time of school entry persist over time, or do they quickly dissipate? Third, do the effects differ depending on children's family background or characteristics of subsequent schooling?

We use data from the newly available Early Childhood Longitudinal Study Kindergarten Class of 1998-99 (ECLS-K), a large, nationally representative sample of children who entered kindergarten in the fall of 1998. The ECLS-K collects data on school performance and a rich array of family background, school, and other control variables, including early education and child care experiences. Data are available currently through the spring of 2000, when most children are completing first grade. The outcomes we examine are reading and math

\footnotetext{
${ }^{1}$ The Education Commission of the United States (2003) provides an up to date summary of state activities in early education.
} 
skills, and classroom self-control and aggression. We assess school readiness using data from the fall of kindergarten, and the persistence of effects with information from the spring of first grade.

A significant challenge is to adequately control for differential selection into early education programs. For example, favorable selection, whereby parents whose children attend prekindergarten possess characteristics resulting in high levels of school performance, would result in a spurious positive correlation between preschool enrollment and later outcomes. Our primary econometric strategy is to use the detailed information available in the ECLS-K to measure many potential confounding factors. We also estimate models that instrument prekindergarten attendance with state expenditures on these programs.

Our main results are as follows. 1) Prekindergarten significantly increases math and reading performance at school entry - effect sizes range from 0.10 to 0.13 in the preferred models. 2) Prekindergarten attendance increases aggression and decreases self-control (with effect sizes of 0.09-0.12). 3) Other types of center-based child care have positive effects on academic outcomes and negative effects on behavior, although in both cases these are smaller than for prekindergarten. 4) For most children, the cognitive benefits of prekindergarten quickly fade, but the behavioral effects persist. 5) However, there are more lasting cognitive gains for disadvantaged children and for those experiencing minimal levels of instruction in the early school years. This last finding suggests that further expansions of prekindergarten should be mainly focused on children who are disadvantaged or who will go on to attend low instruction schools. 


\section{Prior Research}

The benefits from high-quality intensive early education interventions are well documented and include short-term improvements in cognitive and language development as well as long-term increases in academic achievement and reductions in special education placement and grade retention (see Barnett, 1995; Currie, 2000; Karoly et al., 1998; BrooksGunn, 2000; Farran, 2000; Ramey and Ramey, 2000; Vandell and Wolfe 2000; Waldfogel, 2002). However, we know much less about the effects of more typical preschool or prekindergarten programs (Gilliam and Zigler, 2001). Lacking experiments, researchers have used naturally occurring variation in families' use of child care arrangements to assess the effects. Unfortunately, these analyses often include only a few controls for potential selection factors, raising the possibility that the resulting associations are spurious rather than causal (Blau, 2001; Currie, in press). Methodological concerns notwithstanding, the bulk of evidence suggests that center-based care during the third and fourth year of life promotes academic outcomes at school entry (Barnett, 1995; Gilliam and Zigler, 2001; NICHD ECCRN, 2002b; NICHD ECCRN and Duncan, 2003). ${ }^{2}$

Many of the advantages bestowed by early education fade by the time children are in their second or third year of formal schooling (Barnett, 1995), as children not attending early education programs catch up to those who did. In response, some researchers suggest that subsequent schooling experiences are key to understanding whether early education program effects persist, but exactly how later schooling matters is unclear (Takinishi and DeLeon, 1994). One possibility is that children without early education who experience high levels of academic

\footnotetext{
2 The Head Start program has also been extensively studied with non-experimental research designs. However, selection bias is a major problem, given the disadvantaged nature of the Head Start population. Studies most successfully addressing this issue tend to find the most positive and long-lasting academic benefits (e.g. Currie and Thomas, 1995; Garces et. al. 2001).
} 
instruction in the first years of school catch up to their peers more quickly than those who experience lower levels of instruction. However, other scholars speculate that "skills beget skills" and therefore children entering elementary school with a higher level of academic skills may be uniquely poised to gain from subsequent instruction (Carneiro and Heckman, in press).

Although cognitive outcomes have tended to receive most attention in the economics literature, school readiness and later school success also depend on behavior adjustment (RimmKaufman et al., 1998; Shonkoff and Phillips, 2000). When teachers are asked to describe the key components of school readiness, positive behavior including enthusiasm, cooperation, following directions, and not disrupting the class are rated as more important than knowing specific skills such as letters of the alphabet or counting numbers (Lewit and Baker, 1995). Furthermore, high levels of aggressive behavior and low-levels of self-control predict lower academic achievement, although whether these associations are causal remains controversial (Alexander, Entwisle, and Dauber, 1993; Hinshaw, 1992).

Non-experimental evidence indicates that early and extensive non-maternal child care, particularly center-based care, is associated with higher levels of behavior problems in school (see review in Belsky, 2001; NICHD ECCRN, 2003). However, evidence is mixed as to whether attending center-based care or early education programs during the year or two prior to school entry has detrimental effects on behavior. ${ }^{3}$

Particular types of early education programs may contribute to behavior problems. Stipek and colleagues (1998) found that early education programs with teacher-directed basic skill instruction had negative social climates, measured by teachers' warmth and nurturance and

\footnotetext{
${ }^{3}$ For example, an experimental evaluation of the Perry Preschool program, a model program serving 3 and 4 year olds, indicated that the program had no effect on school misbehavior (Schweinhart, Barnes, and Weikart, 1993). However, non-experimental studies have found that children in center-based care for a larger proportion of the year prior to kindergarten had higher levels of problem behavior in kindergarten (Bates et al., 1994).
} 
frequency of rewarding positive behavior rather than disciplining negative behavior.

Furthermore, attending a preschool or kindergarten with a basic-skills emphasis was associated with having higher levels of problem behavior, compared to attending programs with lower levels of basic skill instruction and more child-directed learning approaches. Because this study relied on naturally occurring variation in early education experiences, it was unable to determine whether classrooms that combined basic skills instruction with a positive social climate are associated with behavior problems. However, Stipek and colleagues (1998) suggest that model programs, such as Perry Preschool, may not have detrimental effects because the caregivers are able to provide basic skills education while fostering positive social environments.

Taken together, the prior literature suggests that early education may increase children's academic skills but also children's misbehavior. However, prior research has been limited because most experimental studies have been based on model programs serving small nonrepresentative samples. In contrast, larger and more representative studies have generally used naturally occurring variation in children's experiences, but have typically included only a few covariates in analyses, and consequently have not adequately addressed the selection biases that may pervade non-experimental designs (Duncan and Gibson, 2000).

Moreover, nearly all studies have combined all types of early education programs into one category even though the effects may differ depending on the quality and emphasis of the programs. With the exception of Head Start, few studies have considered whether specific types of preschool programs are more or less beneficial than other early education programs. Childstaff ratios, class sizes, and caregiver education and pay are important determinants of the quality of care (NICHD, 2002a; Phillips, Mekos, Scarr, McCartney, and Abbott-Shim, 2001), and data 
on these indicators suggest that school-based prekindergarten provides relatively high quality care (Ripple et al., 1999; Smith et al., 2003). ${ }^{4}$

Only one previous study has analyzed prekindergarten programs as distinct from other types of preschool or center-based care. Using data from the ECLS-K, Magnuson and colleagues (in press) provide evidence that prekindergarten programs may confer larger academic benefits than other center-based programs, with particularly large gains for disadvantaged children.

However, the effects on behavioral outcomes were not considered, and concerns about bias due to the differential selection of children into prekindergarten programs were not thoroughly addressed.

This study addresses five limitations of prior research. First, we examine the effects of different types of early education programs using a large and nationally representative sample. Second, we consider the impacts on behavior problems as well as academic skills. Third, we are able to better deal with selection effects due to the extensive array of child, family background, school, and classroom characteristics included in our data set, and by using IV methods to test the robustness of the findings. Fourth, we analyze whether the differences observed at school entry persist over time or fade out. Fifth, we evaluate whether the impacts differ as a result of the child's family background or the type of academic instruction received during kindergarten and first grade.

\section{Data}

Data are from the Early Childhood Longitudinal Study, Kindergarten Cohort of 1998-99 (ECLS-K), a nationally representative sample of children attending kindergarten in the fall of 1998. Designed and carried out by the U.S. Department of Education, the ECLS-K collected

\footnotetext{
${ }^{4}$ For example, $86 \%$ of school-based prekindergarten teachers have a four-year college degree (Smith et al., 2003), which is more than twice the rate among center-based care program workers (Blau, 2001). Existing data do not indicate whether prekindergarten classrooms have positive social climates.
} 
data over children's first two years of school. We use information from the fall of 1998 (kindergarten) and spring of 2000 (for most children, first grade). The ECLS-K includes academic assessments, child, parent, teachers and school administrator surveys, and observational ratings of school environments. Our sample consists of 9,547 children entering kindergarten (for the first time) in the fall of $1998 .^{5}$ This sample size reflects the exclusion of 3,555 children in the fall of kindergarten for whom information on child care/early education or one of the outcomes was missing. ${ }^{6}$ Similarly, 4,651 children for whom data was not collected in the spring of first grade were dropped from the sample. This large number of exclusions partially reflects planned attrition (only half the children changing schools after the fall of kindergarten were retained in the study), as well as lower completion rates among children followed after changing schools ( $64 \%$ compared with $95 \%$ for non-movers). ${ }^{7}$

\section{$\underline{3.1 \text { Outcomes }}$}

During the fall of kindergarten and the spring of first grade, children's math and reading skills were assessed during one-on-one testing sessions. ${ }^{8}$ The assessments were created especially for the ECLS-K by a team of experts, with some items adapted from existing instruments. The reading test assessed knowledge of letters and word recognition, beginning and

\footnotetext{
${ }^{5}$ The ECLS-K had high completion rates with close to $90 \%$ of children and teachers, and $85 \%$ of parents participating in the study in the fall of kindergarten, and non-response did not differ by child or family characteristics, with the exception that parents of Asian children were slightly less likely to complete parent interviews, due to language barriers (National Center for Education Statistics, 2001).

${ }^{6}$ About $30 \%$ of those who were excluded in the fall of kindergarten were non-English speaking, and therefore were not administered reading assessments. Just over 50\% were missing parent report data and an additional 676 were excluded because they were repeating kindergarten in 1998, or because data for this measure was missing. We also excluded children with missing outcome data in the spring of kindergarten $(\mathrm{N}=268)$ and 44 children because the sizes of missing data cells were too small to be included in our first stage IV analyses. Robustness checks performed by adding these children back to the sample did not substantively change any of the results. ${ }^{7}$ Overall completion rates were high among those children who were followed through the spring of first grade, with $92 \%$ of child assessments, $86 \%$ of parent interviews, and $83 \%$ teacher interviews completed (National Center for Education Statistics, 2002).

${ }^{8}$ As noted above, children were also assessed during the spring of kindergarten but we do not use those data here. A brief language screener was given to children who were identified as having a non-English background by teachers or school records. If they failed the screener, children received a reduced version of the assessments, and were not included in our sample.
} 
ending sounds, vocabulary, and passage comprehension. The math test evaluated understanding of numbers, geometry, and spatial relations. Reported reliabilities for the tests were quite high for all assessments (National Center for Education Statistics, 2001).

The math and reading outcomes are transformations of latent ability scores into standardized t-scores that have a mean of 50 and standard deviation of 10 (based on the full sample distribution). ${ }^{9}$ Consequently, the scores should be interpreted as children's ability relative to their peers, and can be translated into effect sizes by dividing regression coefficients by 10 . The sample analyzed scored slightly above the full sample mean at school entry and during first grade, with average reading and math scores around 52. ${ }^{10}$ The 3 percent of children still in kindergarten in the spring of 2000 were classified as having repeated kindergarten (since they should have progressed to first grade by the fall of 1999).

Teacher reports of children's externalizing behavior and self-control are included to measure children's classroom behavior. ${ }^{11}$ Externalizing problem behavior refers to aggressive behavior as indicated by a five-item scale providing information on how frequently the child fights, argues, gets angry, acts impulsively, or disturbs ongoing activities. Self-control is comprised of four items about how frequently the child respects the property of others, controls their temper, accepts peer ideas for group activities, and appropriately responds to peer

\footnotetext{
${ }^{9}$ The skills tests were conducted in two-steps. Children were first given common questions as a routing section. The second set of questions differed in difficulty, depending on performance in the first step. Because children did not answer the same questions, the resulting score was calculated using Item Response Theory (IRT), which uses patterns of right, wrong, and missing answers and the difficulty of questions asked to place each child on a continuous ability scale. The resulting latent score is an estimate of the number of questions that child would have been correctly answered had the child been asked all available questions.

${ }^{10}$ This partially reflects our exclusion of children who are repeating kindergarten, are not proficient in English or who transferred schools.

${ }^{11}$ These are adapted from the Social Rating System (SRS, Gresham and Elliot, 1990).
} 
pressure. ${ }^{12}$ The final scores were standardized (for the full sample), to have a mean of 0 and a standard deviation of 10 . As with academic skills, these scores can be translated into effect sizes by dividing regression coefficients by 10 , allowing us to compare behavior and academic outcomes using a similar metric.

\subsection{Early Child Care and Education}

Using parental responses to questions asked about child care in the year prior to kindergarten, children were classified as having attended a prekindergarten program, other types of center-based care (subsequently referred to as preschool), Head Start, or other non-parental care (care by a relative or non-relative, e.g., nanny or babysitter). To simplify interpretation of the regression coefficients and isolate the effects of prekindergarten, we constructed mutually exclusive groups. ${ }^{13}$ Using these categories, $46 \%$ of child care was preschool, $17 \%$ prekindergarten, $16 \%$ exclusively parental care, $12 \%$ other types of non-parental care, and $10 \%$ Head Start.

A potential concern is that we are not able to determine how parents distinguish between different types of programs, with misclassification seeming most likely for preschool and prekindergarten. Our presumption is that programs that parents identify as prekindergarten correspond to either school-based programs or publicly funded state prekindergarten initiatives,

\footnotetext{
${ }^{12}$ Externalizing behavior is highly negatively correlated with self-control $(-0.70, \mathrm{p}<.01)$. At school entry, reported frequencies of externalizing behavior were relatively low, with unstandardized means of 1.5 , and rates of selfcontrol were high, with unstandardized scores of 3.12 .

${ }^{13}$ Children experiencing prekindergarten and other non-parental care were placed in the prekindergarten category. Those with preschool and other non-parental care were put in the preschool group. Children in Head Start and other non-parental care were coded as having attended Head Start. Those with both Head Start and other center-based care (preschool or prekindergarten) were categorized according to the type of care where they spent the greatest number of hours per week. Approximately 34\% of children in prekindergarten, $35 \%$ in preschool, and $41 \%$ in Head Start were also in other non-parental care arrangements. Overlap between preschool or prekindergarten and Head Start was much lower. Only 7\% of children who attended prekindergarten and 5\% in preschool were also in Head Start. The results of models estimated with non-exclusive child care categories were nearly identical to those reported..
} 
and are thus more explicitly educational than other types of center-based care. ${ }^{14}$ One reassuring piece of evidence is that the $17 \%$ prekindergarten enrollment rate for this sample is close to the $14 \%$ national estimate recently obtained by Smith et al. (2003). Any classification errors seem likely to attenuate the parameter estimates, such that the regression results probably understate the true effects.

\subsection{Additional Explanatory Variables}

Most of the regressions contain exhaustive controls for child, family background, and neighborhood characteristics, exploiting the rich information contained in the ECLS-K. Our goal is to include covariates that either directly affect child outcomes or proxy unobserved characteristics. Thus, most models control for demographic and family characteristics such as race/ethnicity, age, health status at birth, height, weight, and gender, the household income-toneeds ratio, parental education, region of the country, family structure and size, and language spoken in the home. Appendix Table 1 provides details on all of the covariates.

Also incorporated as covariates are measures of the child's home environment created from parent survey data collected in the fall and spring of kindergarten. ${ }^{15}$ These include a diverse set of home and family resources and parenting practices that may be related to early child care, education experiences, academic skills, and behaviors. The learning environment is proxied by a range of activities such as reading books and singing songs, children's participation in structured activities outside of the home, their use of home computers, and the number of books in the home. There are also indicators of the parent's expectations of the child's educational attainment and attitudes about the importance of particular skills, controls for the family members'

\footnotetext{
${ }^{14}$ Although parents with children in private school kindergarten disproportionately report prekindergarten attendance, separate analyses of these children yielded similar results for academic outcomes as those reported. However, for this subsample, preschool did not appear to have any negative effects on children's behavior problems.

${ }^{15}$ Parent surveys were primarily conducted with mothers. If the child's mother was unable to complete the interview, another knowledgeable adult in the household did so.
} 
involvement in the child's schooling, parental responses to questions about the warmth and affection of the relationship with their child, the frequency of physical discipline, a composite measure of the parent's depressive symptoms, and several variables measuring the regularity of the family routines (like eating meals together) ${ }^{16}$

To proxy the effects of neighborhood and state characteristics, we included a neighborhood quality composite index (constructed from parent responses to questions about the prevalence of crime, abandoned buildings, drugs, and safe places for children to play in the neighborhood), as well as state level measures of the log of per capita income and public spending on public welfare and education programs in 1998. Data for these state variables are taken from US Bureau of the Census (2001).

Data on one or more background characteristics are lacking for some children. ${ }^{17}$ To retain these cases, the relevant regressors are set to zero and dummy variables created to denote the presence of missing values. For example, for children missing data on parental reports of birth weight, the two low birthweight variables were recoded to have a value of zero, and a dummy variable indicating missing data on birthweight was created.

To measure children's exposure to academic instruction, we combine two items from teacher surveys conducted in the fall of kindergarten and spring of first grade about how much time children spend working on projects or lessons about math and reading. We categorized classes that spent an hour or less combined on reading and math skills as "minimal" instruction

\footnotetext{
${ }^{16}$ Because most family characteristics are measured during kindergarten, they could be influenced by prekindergarten (or other preschool) attendance. In most cases, this problem is likely to be minor (e.g. parents are unlikely to base meal routines on the availability of prekindergarten). However, some components of the home learning environment could be shaped by the early education experiences. For instance, parents may be instructed by prekindergarten teachers to frequently read to their children or receive information about the availability of structured activities such as art classes. If so, the inclusion of these covariates may absorb a portion of the effect of prekindergarten (or preschool), resulting in biased estimates. Generally, this seems likely to lead us to understate any positive effects of prekindergarten, but over estimate any negative effects.

${ }^{17}$ Rates of missing data are quite low, below $2 \%$ for most child and family characteristics.
} 
classrooms. About $12 \%$ of children were in minimal instruction classrooms in kindergarten and about $1 \%$ in first grade.

Finally, we estimated a series of instrumental variables (IV) models, using a measure of access to state prekindergarten as an instrument. To estimate the proportion of poor children under five with access to a publicly funded prekindergarten, we divided a state's prekindergarten spending by the number of poor children under 5 (since most states target prekindergarten programs to economically disadvantaged children) and calculated this as a fraction of the average cost of center-based care for four-year-olds. ${ }^{18}$ This share ranges from 0 to 0.33 .

\section{Methods}

Conceptually, we can think of outcomes for child $\mathrm{i}$ in state $\mathrm{j}\left(\mathrm{O}_{\mathrm{ij}}\right)$ as being "produced" by a series of inputs such as the non-market "leisure" time of parents, purchased inputs like educational resources provided in the home, and nonparental child care provided prior to school entry. We do not attempt to determine the structural parameters of this child production function. Instead, most models estimate the reduced-form association between experiences in the year prior to kindergarten and early school outcomes, after controlling for a comprehensive set of explanatory variables.

The basic regression equation is:

$$
\mathrm{O}_{\mathrm{ij}}=\operatorname{PREK}_{\mathrm{ij}} \beta+\mathrm{X}_{\mathrm{ij}} \gamma+\mathrm{S}_{\mathrm{j}} \delta+\varepsilon_{\mathrm{ij}}
$$

Outcomes are measured in the fall of kindergarten and spring of the first grade. PRE is a dummy variable for prekindergarten attendance. $\mathrm{X}$ is a set of child, family, and neighborhood characteristics, and $\mathrm{S}$ is vector of state characteristics. Because schools were the primary

\footnotetext{
${ }^{18}$ Information on state prekindergarten spending and the cost of center-based care was taken from Blank et al. (1999); estimates of the number of poor children under age 5 were from US Census Bureau (2003).
} 
sampling unit in the survey, in all analyses we correct the standard errors for non-independence of observations within schools.

Because equation 1 does not include controls for types of care other than prekindergarten, $\hat{\beta}$ captures the difference in outcomes between children who attended prekindergarten and those experiencing any other type of care (including parental care). However, we also estimate models that add controls for preschool, Head Start, and other non-parental care. These analyses estimate the effects of prekindergarten and other forms of nonparental care, relative to children experiencing only parental care.

One strategy in our analysis is to include a sufficiently rich set of covariates that the error term in (1) is orthogonal to $\mathrm{O}_{\mathrm{ij}}$. However, a potential concern is that even our extensive set of controls may not fully account for the selection into prekindergarten. For this reason, we also present results for instrumental variable (IV) estimates, where the level of state spending on prekindergarten programs (adjusted for the number of children in poverty and the cost of care) instruments prekindergarten enrollment. The first-stage equations for this analysis is:

$$
\text { PREK }_{\mathrm{ij}}=\operatorname{STEXPEND}_{\mathrm{j}} \beta+\mathrm{X}_{\mathrm{ij}} \gamma+\mathrm{S}_{\mathrm{j}} \delta+\varepsilon_{\mathrm{ij}}
$$

Because PREK $\mathrm{ij}_{\mathrm{j}}$ is dichotomous, (2) is estimated as a probit model. The second stage is then estimated by OLS, using Huber-White estimation to correct standard errors for the clustering of data at the school level, and additional corrections for the two-stage estimation process (Murphy and Topel, 1985). ${ }^{19}$ As detailed below, state prekindergarten expenditures predict attendance quite well and are likely to be a satisfactory instrument.

\footnotetext{
${ }^{19}$ The IV standard errors are not corrected for the fact that the spending variable takes the same value for all children in a given state. Doing so would probably increase the standard errors. We have not undertaken this correction since we are primarily using the IV models to detect the direction of any remaining bias in the OLS estimates, rather than to estimate the magnitudes of the effects from the IV regressions. Ideally, we would have also included other types of care in our IV models. However, we did not do so because it is more difficult to find good instruments for other types of child care (e.g., preschool). We did consider using federal spending on child subsidies
} 


\section{Descriptive Statistics}

Table 1 provides the means and standard errors for all outcomes for the full sample and for subsamples stratified by the type of care in the year prior to kindergarten. Children who attended prekindergarten or preschool have the highest test scores, followed by those exclusively in parental care or receiving other types of non-parental care (e.g., babysitters); Head Start enrollees have the lowest scores in math and reading. Conversely, children who were in exclusive parental care have the best behavior (highest levels of self-control and lowest levels of externalizing behavior). Finally, children who attended prekindergarten were least likely to repeat kindergarten, followed by those who attended preschool.

The sample characteristics provided in the bottom panel of Table 1 suggest that differing family backgrounds may account for at least part of the disparities in the outcomes. For example, children experiencing prekindergarten or preschool programs typically come from relatively advantaged families as indicated by their family income. Thus, although states have primarily targeted funding of prekindergarten programs to disadvantaged children, nondisadvantaged children also have access to prekindergarten. ${ }^{20}$

\section{Does Prekindergarten Improve School Readiness?}

Table 2 presents results from regressions of children's academic and behavioral outcomes in the fall of kindergarten on prekindergarten attendance, with increasing levels of controls for potential selection effects. As in Table 1, absent other controls, model (1) shows that

as additional instruments. However, child care funding across states is based on a formula that is largely determined by the number of low-income children within a state (identified by the number of children who qualify for free and reduced lunch), a state's prior level of spending on child care for welfare recipients, and their ability to match and draw down federal funds (Gish, 2002). Consequently, variation across states in the proportion of publicly funded slots available to low income children is much smaller than for prekindergarten funding, and much more likely to be driven by error in measuring either the number of poor children or the cost of care per child.

${ }^{20}$ Because family poverty is one criterion for Head Start enrollment, it is no surprise that children attending Head Start programs had the lowest household income-to-needs ratios. 
prekindergarten is positively and strongly associated with reading and mathematics skills -children enrolled in prekindergarten have reading scores 3.17 points higher than other children. As shown in models (2) through (4), the addition of covariates reduces the prekindergarten effects by 60 percent, most of which is due to the inclusion of demographic characteristics.

We focus below on the results of the most comprehensive specification (model 4), because this model includes controls for many family and neighborhood conditions and is likely to best account for potential selection factors. In this case, prekindergarten attendance predicts a statistically significant 1.26 higher reading score and 0.93 higher math scores, corresponding to an effect size of 0.13 and 0.09 respectively. This represents about one more question answered correctly, and effects of this size would move the average child from the $50^{\text {th }}$ to the $55^{\text {th }}$ percentile for reading and from the $50^{\text {th }}$ to the $54^{\text {th }}$ percentile for math. ${ }^{21}$ The large number of covariates included and small changes in estimated effects observed with the addition of more controls (beyond the basic demographic variables) increase our confidence that these estimates may represent causal effects, rather than remaining heterogeneity. We use IV models in the following section to further test this assumption.

By contrast, teachers report that children who attended prekindergarten exhibit statistically significantly more externalizing (aggressive) behavior than their counterparts and insignificantly lower levels of self-control (Table 2, model 1). The addition of covariates has virtually no effect on the estimates for externalizing behavior (effect sizes are 0.12 in all four models) and slightly increases the negative associations with self-control - to an effect size of 0.09 (Table 4 model 4). Effects of these magnitudes imply that prekindergarten is predicted to

\footnotetext{
${ }^{21}$ Percentile changes were calculated by converting the standardized scores into percentile scores using the cumulative distribution function (cdf), determining the corresponding position in the cdf, and then adding the estimated effect size of prekindergarten. The resulting value was translated back into a percentile using the cdf.
} 
raise children from the median to the $55^{\text {th }}$ percentile of externalizing behavior, and lower them to the $46^{\text {th }}$ percentile of self-control. ${ }^{22}$

\section{IV Estimates}

The OLS estimates, discussed above, suggest that prekindergarten has positive effects on academic outcomes, but negative effects on classroom behavior. We have included an exceptionally rich set of controls for potential confounding factors, increasing our confidence that these results may indicate causal relationships. Nevertheless, it is possible that some sources of selection bias remain, even after including the exhaustive set of covariates. We address this possibility by conducting a set of instrumental variables (IV) estimates.

In the late 1990s, spending on prekindergarten varied greatly across states, and we take advantage of this by using state spending as an instrument for prekindergarten participation. Figure 1 displays how spending on prekindergarten (per poor child under five years of age) varied in 1998 for the 39 states in which children in the ECLS-K study reside. ${ }^{23}$ Some states (e.g., Connecticut, Georgia, New Jersey, and Massachusetts) were making substantial investments in prekindergarten, but at least 10 states are not investing any money at all. In constructing our instrument, we further divide state prekindergarten expenditures (per poor children under five) by the average cost of center-based care in the state. This provides a measure of the proportion of poor children with access to publicly funded kindergarten.

It is plausible that access to state-funded programs will predict prekindergarten enrollment and have no independent effect on child outcomes (other than through its effect on

\footnotetext{
${ }^{22}$ One concern about using teacher reported outcomes is that children who attended kindergarten may be selected into different classrooms than other children. A solution is to estimate teacher-fixed effect regressions, which compares children who attended prekindergarten with children in their classrooms who did not. Results from such analyses are somewhat smaller but consistent with the OLS findings - prekindergarten effects from teacher fixedeffects models are about 0.80 for reading, 0.73 for math, -0.66 for self-control, and 0.88 for externalizing behavior. Very similar results are obtained from models with school fixed-effects.

${ }^{23}$ We use funding during the 1998-1999 school year because data are unavailable for 1997-1998, the year these children would have attended prekindergarten programs.
} 
enrollment) ${ }^{24}$ Results from the first stage indicate that state spending significantly predicts children's participation - the probit estimates indicate that a 10 percentage point increase in the number of available slots in a state increases the probability of prekindergarten attendance by a highly significant 2.5 percentage points, from the base rate of $17 \%$. The Chi-square statistic for the test of the instrument's significance is 25.4 , well above the recommended guideline of 10 (Bound, Jaeger, and Baker, 1995).

Results from the second stage are presented in Table 3. For comparison purposes, the first row repeats the OLS effects obtained in model 2 of Table 2. The IV estimates are always in the same direction as but much larger than the corresponding OLS effects. For example, the IV model suggests an effect size of prekindergarten on reading of 0.73 , compared to an OLS effect size of 0.13 . For externalizing behavior, the IV estimates predict a prekindergarten effect size of .71 , whereas the OLS effect size is .12. In all cases, the predicted effects are much larger for the IV estimates than for the OLS estimates. Our conclusion is that these results provide no indication that the OLS results are biased upwards.

A potential concern with using spending as an instrument is that states that invest money in prekindergarten may also invest in other programs that benefit children. If so, the instrument could be correlated with the regression error term leading to biased IV estimates. Both the OLS and IV estimates shown in Table 3 include controls for two state characteristics-- per capita income and per capita spending on education and public welfare. We tested the sensitivity of our IV estimates to the inclusion of other state policies and characteristics, by estimating alternative specifications with additional measures of state level policies and characteristics including proxies for generosity of the welfare system (TANF benefit levels and rules, Medicaid spending)

\footnotetext{
${ }^{24}$ State spending for prekindergarten programs is a state policy decision and is unlikely to be linked to the characteristics of children and families within a state, and so may be exogenous.
} 
and the state's political climate (e.g., the percent of representatives in the House and Senate that are Democrats, percent of state population that is female, elderly, or black). Our findings were robust to these specification changes. ${ }^{25}$

\section{Prekindergarten Versus Other Preschool Child Care Arrangements}

Like prekindergarten, preschools and many center-based child care programs provide curriculums designed to promote academic skills and enhance school readiness. However, because structural indicators, such as levels of teacher education, suggest that prekindergarten programs are typically of higher quality, we expect that other early education programs will have positive effects on achievement, but that the benefits may be smaller. It is less clear how the other types of early child care and education will be related to behavior. Although high quality care is associated with lower levels of problem behavior (Peisner-Feinberg et al., 2001), there may be features of prekindergarten, such as teacher directed basic skill instruction, that are associated with less positive social climates and thus more behavior problems. We expect Head Start to have less positive effects on academics and more detrimental effects on behavior outcomes because the quality of Head Start centers varies greatly and is often quite poor, partly due to low levels of funding.

The top panel of Table 4 displays the findings of models that include measures of participation for prekindergarten, preschool, Head Start, and other non-parental care (e.g., babysitters or relative care), with children receiving only parental care as the reference group. The results support a "dose-response" model. For all academic outcomes, prekindergarten is predicted to yield consistently larger benefits than preschool. For instance, prekindergarten's

\footnotetext{
${ }^{25}$ For example, IV estimates in models that controlled for the average level of welfare benefits yielded effect sizes of 0.73 for reading and 0.79 for externalizing behavior.
} 
effect size for reading is 0.19 and for math is 0.17 . Preschool's effects are about 0.12 for both reading and math.

We also find a dose-response pattern for classroom behavior but, in this case, with prekindergarten having larger adverse effects than other types of center-based care. The effect size of prekindergarten is -0.13 for self-control and 0.19 for externalizing behavior as compared with -0.06 and 0.13 respectively for other types of preschool. ${ }^{26}$

Head Start enrollment is associated with higher levels of externalizing behavior and possibly lower levels of self-control, but is less strongly related to academic outcomes, whereas care in non-center-based settings has no effect on academic skills, but may be associated with lower levels of problem behaviors.

\section{Do the Effects of Prekindergarten Persist?}

The OLS and IV results indicate that prekindergarten boosts children's reading and math scores, but also increases classroom misbehavior during the fall of kindergarten. However, prior research has found that early academic advantages associated with preschool fade over time, lasting only through one or two years of elementary school (Barnett, 1995). The extent to which the effects fade out over time may have important policy implications since the case for using public funds to invest in early education is likely to be weakened if the academic gains are only temporary, rather than lasting.

We address this issue in the lower panel of Table 4, by presenting estimates for academic and behavior outcomes measured in the spring of the first grade (2000). Compared to the kindergarten fall results (displayed in the top panel), the positive effects of prekindergarten on

\footnotetext{
${ }^{26}$ On average children were attending prekindergarten for longer hours than preschool (23 vs. 20). However, the predicted effects of prekindergarten remain larger when comparing children in similar hours of care. More generally, longer hours of prekindergarten were associated with larger positive benefits for academics and negative effects on behavior. Longer preschool hours were also associated with larger effects on behavior, but not on academics.
} 
academic outcomes have largely dissipated - effect sizes are 0.04 for reading and 0.05 for math, which is only one-third to one-fourth as large as those obtained in the fall of kindergarten. In contrast, the negative effects of prekindergarten on classroom behavior persist and actually have increased in size by the spring of first grade - effect sizes are -0.14 for self-control and 0.23 for externalizing behavior. ${ }^{27}$

Children attending early education programs prior to kindergarten are 4 to 6 times more likely than their counterparts to be in center-based care before or after school in kindergarten and first grade. ${ }^{28}$ To test whether this accounts for some of the previously observed negative effects on behavior, we estimated models that added covariates for attending center based care in kindergarten and first grade. Doing so reduced the effect size of prekindergarten from 0.23 to 0.20 for externalizing behavior, and from -0.14 to -0.12 for self-control, suggesting that the adverse effects of early education programs on behavior persist, but do not increase over time. ${ }^{29}$

These results --- that prekindergarten raises academic achievement (although possibly only temporarily) while having persistent negative effects on classroom behavior -- raise the question as to whether prekindergarten does more harm than good. Although we cannot definitively answer this question, we do note all three types of formal education are associated with lower probabilities that the child will be held back in kindergarten, although with such a small share (3\%) of children being retained, the estimates are small and statistically insignificant.

\section{Does School Instruction Influence the Persistence of Effects?}

\footnotetext{
${ }^{27}$ Effects of this magnitude would raise the average first-grader's position in the externalizing distribution from the $50^{\text {th }}$ percentile to the $56^{\text {th }}$ and lower the child from the $50^{\text {th }}$ to the $44^{\text {th }}$ percentile in the self-control distribution. Negative effects on children's behavior are still apparent for Head Start.

${ }^{28}$ The rates of center-based care in kindergarten, by type of care children were in the prior year, are as follows: prekindergarten 29\%; preschool 29\%; Head Start 5\%; Other non-parental care 10\%; Parental care 5\%. In the spring of first grade: prekindergarten 25\%; preschool 22\%; Head Start 9\%; Other non-parental care 12\%; Parental care 7\%.

${ }^{29}$ Coefficients for center-based care in kindergarten and first grade indicate large negative effects on behavior. For instance, the effect sizes of center-based care on externalizing behavior are 1.40 in kindergarten and 1.65 in first grade.
} 
Researchers have suggested that the effects of preschool fade because children without prior early educational experiences "catch up" to their peers when they enter formal schooling. ${ }^{30}$ This suggests that the persistence of prekindergarten effects may vary with the amount of instruction received in subsequent schooling, with smaller and perhaps less persistent effects of early education found for children in classrooms with greater amounts of academic instruction. We consider this possibility by examining a subsample of children who are in minimal instruction classrooms during the fall of kindergarten and the spring of first grade $(n=1,240) .{ }^{31}$

The results of this analysis, presented in Table 6, suggest that prekindergarten (and to a lesser extent preschool) has larger and more persistent effects on academic outcomes for students in low instruction classrooms than other children. For example, the effect size of prekindergarten on reading is 0.46 at school entry and 0.25 in the spring of first grade, compared to 0.19 and 0.04 for all children. ${ }^{32}$ On average children were scoring at the $50^{\text {th }}$ percentile in reading in these classrooms, and attending prekindergarten would raise their score to the $68^{\text {th }}$ percentile at school entry and the $60^{\text {th }}$ percentile by the spring of first grade. Moreover, in contrast to the full sample, prekindergarten is associated with large reductions in grade retention in kindergarten, with substantial benefits also observed for preschool and Head Start. However, given that we have not modeled children's selection into classrooms, we note that these results should be interpreted with caution.

Smaller differences are observed for classroom behavior. Predicted effects of prekindergarten on externalizing behaviors are larger for children in low instruction classrooms

\footnotetext{
${ }^{30}$ Consistent with this, we find slightly larger effects of preschool and prekindergarten for children tested earlier in the school year (e.g. prekindergarten effect sizes for math are 0.19 for children tested in October and 0.15 for those tested in November). Interestingly, this pattern does not hold for children's classroom behavior. For example, effect sizes of prekindergarten on externalizing behavior are 0.20 in both October and November.

${ }^{31}$ Minimal instruction is defined as spending less than an hour a day combined on reading and math instruction.

${ }^{32}$ Analyses with interaction terms for low instruction by prekindergarten indicate that the effects on reading and math at school entry and reading at spring of first grade are significantly different for children in low instruction classrooms compared to children in classrooms with greater amounts of academic instruction.
} 
than for the general population both at school entry (effect sizes of 0.27 vs. 0.19 ) and in the spring of first grade ( 0.28 vs. 0.23$)$ but insignificantly lower for self control in the fall of kindergarten (-0.10 vs. -0.13$)$ and identical in the spring of first grade ( -0.14 vs. -0.14$)$

In summary, these results provide some indication that early education may have longer lasting effects for children provided with little academic instruction in the first years of school. However, the fact that these effects are larger even in the fall of kindergarten suggests that selection into these types of classrooms may also be a factor.

\section{Disadvantaged Children}

Prior studies have suggested that early education programs have larger effects for economically disadvantaged populations, primarily because these children come from homes with lower quality learning environments (Karoly et al., 1998; Peisner-Feinberg et al., 2001; Waldfogel, 2002). Next, we consider this issue, employing two definitions of economic disadvantage. The first defines disadvantage broadly, including children in poverty (income-toneeds ratio of less than one) or whose mother or father who did not complete high school. The second definition is more narrow, children whose parent reported receiving welfare during the fall or spring of kindergarten. ${ }^{33}$ Table 6 summarizes the results of analyses with these subsamples.

As expected, the estimated effects of prekindergarten and preschool on academic outcomes are slightly larger for disadvantaged children than the general population. For example, the effect size of prekindergarten on reading scores at school entry is 0.28 for disadvantaged children (see Table 6), compared to 0.19 for the full sample (Table 2). To put this in perspective, the average disadvantaged child (in poverty or with an uneducated parent) scored

\footnotetext{
${ }^{33}$ Using other specifications of disadvantage (e.g., living in a single parent family) yield similar results. Surprisingly, only $9 \%$ of disadvantaged children (using either definition) were in minimal instruction classrooms compared to about $13 \%$ of non-disadvantaged children.
} 
at the $33^{\text {rd }}$ percentile in reading; attending prekindergarten would raise their predicted performance to the $44^{\text {th }}$ percentile. The effects of prekindergarten on disadvantaged children's academic outcomes also last longer. By spring of the first grade, the effect sizes for the two disadvantaged groups are 0.20 and 0.23 for math, and 0.09 and 0.21 for reading; these compare with small and non-significant effect sizes for the general population (Table 5). ${ }^{34}$

Prekindergarten does not have consistently larger negative behavioral effects at school entry for disadvantaged children than for the full sample - effect sizes on externalizing behavior are 0.25 for children in poverty or with less-educated parents and 0.15 for children of welfare recipients, compared with 0.19 for the general population. However, prekindergarten's detrimental effects on externalizing behavior increase over time, for both groups of disadvantaged children, such that the effect sizes range from 0.36 to 0.42 by the spring of the first grade, as compared with 0.23 for all children (Table 5). ${ }^{35}$ On average, children in poverty or with less-educated parents are in the $55^{\text {th }}$ percentile of the externalizing behavior distribution; attending prekindergarten is predicted to raise their score to the $69^{\text {th }}$ percentile. Once again, however, prekindergarten does not appear to increase the probability that a child will repeat kindergarten, and in one case reduces this probability.

\section{Discussion \& Policy Implications}

Using new data from the ECLS-K, this analysis suggests that prekindergarten increases school readiness, as measured by math and reading skills at kindergarten entry, but is also associated with an increase in classroom behavior problems. The effect sizes for the academic

\footnotetext{
${ }^{34}$ Analyses with an interaction term for disadvantage by prekindergarten attendance indicate that the effects were significantly larger for both groups of disadvantaged children for one outcome - math in first grade spring. In addition, prekindergarten's beneficial effects on being held back were significantly larger for children from welfare families.

${ }_{35}$ The effect sizes for prekindergarten fall modestly when controls are added for subsequent center-based care in the fall of kindergarten and spring of first grade.
} 
outcomes, compared to children cared for only by parents prior to kindergarten, are 0.19 for reading and 0.17 for math, which would move the average child from the $50^{\text {th }}$ to the $55^{\text {th }}$ and $54^{\text {th }}$ percentiles respectively. Attending (a nonprekindergarten) preschool has similar, but smaller effects (effect sizes of about 0.12 for both outcomes). Conversely, prekindergarten and other preschool attendance are predicted to raise externalizing behavior problems (the effect sizes are 0.19 and 0.13 ) and reduce self-control (effect sizes are -0.13 and -0.06 ). We tested for potential bias in the OLS estimates by conducting a series of IV models using state spending on prekindergarten to instrument attendance. The results suggest that, if anything, the OLS models understate the positive effects on academic skills and negative impact on behavior.

The second major finding is that, for most children, 70 to 80 percent of the cognitive gains associated with attending prekindergarten have faded out by the spring of the first grade (leaving effect sizes of 0.04 and 0.05 for reading and math). In contrast, the correlation with problem behaviors persists over time, suggesting that the early socialization of aggressive behavior and self control may uniquely influence children's later behavior, and that exposure to subsequent formal schooling does not lead to the same levels of aggressive behavior. By the spring of first grade, prekindergarten's effect sizes are about -0.14 for self-control and 0.23 for externalizing behavior. Children attending preschool or prekindergarten are also more likely to attend center-based care during the first two years of formal schooling, which has additional negative effects on children's behavior. Analyses that control for children's experiences of center-based care during kindergarten and first grade indicate that prekindergarten's and preschool's negative behavioral effects persist, but do not increase over time.

Two qualifications are important to understanding the observed negative effects on children's behavior. First, classroom behavior is not necessarily indicative of behavior in other 
settings, so children attending prekindergarten might not exhibit higher levels of aggression at home. Second, in this study, absolute levels of aggressive behavior were typically quite low, and levels of self-control quite high, even for children who attended prekindergarten.

Why might prekindergarten have larger effects on academic outcomes, but also behavior problems, than other forms of child care? As noted, prekindergarten programs usually have relatively high quality, as indicated by structural characteristics of the classrooms such as teacher education and pay, and probably are more academically oriented, which bodes well for children's reading and math skills. However, structured instruction may also cause greater levels of behavior problems if the emphasis on basic skills leads to a less positive social climate in which children receive less individual attention and more punitive discipline (Stipek et al., 1998).

The average effects of prekindergarten and preschool mask considerable heterogeneity among subgroups of children. First, the impacts tend to be larger and longer lasting for children receiving minimal amounts of instruction in kindergarten or first grade. When children who did not attend early education programs are exposed to academic instruction in kindergarten, generally they quickly "catch up" to those who did. However, when children are exposed to only minimal levels of instruction in kindergarten or first grade, the gap between children who have and have not attended early education programs is larger, and persists through the spring of first grade. Classrooms with low levels of academic instruction appear to be slightly more prevalent in schools that serve advantaged children. For example, in this study, classrooms with minimal instruction have lower than average proportions of minority and poor children. If schools with relatively high shares of disadvantaged children provide high levels of basic skills instruction, this may explain why some studies have noted that effects are more likely to fade among disadvantaged children (Currie and Thomas, 1995, 2000). 
Second, the initial benefits of prekindergarten and preschool are much larger for disadvantaged children (with effect sizes of 0.27 for reading and 0.19 to 0.36 for math in the fall of kindergarten). These effects also decline less over time than for the full sample, with the result that effect sizes by the spring of first grade were still substantial, in the range of 0.08-0.21 for reading and 0.20-0.24 for math. However, the effects of prekindergarten on behavioral problems initially are not larger for disadvantaged children than for the full sample, but are more persistent - resulting in effect sizes of 0.36 to 0.46 in the spring of first grade. Yet, we find no evidence that these behavior problems increase grade retention.

Why might children from disadvantaged backgrounds benefit the most from participating in early education programs? One explanation is that they are less likely to experience home environments that facilitate early learning (Bradley, Corwyn, McAdoo, and Garcia Coll, 2001). For example, on average they have fewer books at home, spend less time reading with their parents, and have less stimulating verbal interactions with them than children from middle-class households (Linver, Brooks-Gunn, and Kohen, 2002). Attending a prekindergarten program that provides a cognitively stimulating environment may partially compensate for a less stimulating home environment (Bradley, Burchinal, and Casey, 2001; Caughy, DiPietro, and Strobino, 1994; Hubbs-Tait et al., 2001).

Our findings should be interpreted in light of at least two limitations. First, without data on long-term outcomes, it is difficult to determine how much weight to put on our findings. In particular, it is unclear whether increases in relatively low levels of problem behaviors will be consequential for subsequent schooling outcomes. It is reassuring that although children attending prekindergarten display more problem behaviors in first grade, they were not more likely to be held back. In addition, we need to learn more about happens inside the "black box" 
of prekindergarten. Future research should consider whether these associations are moderated by factors such as prekindergarten group sizes, staffing ratios, and curriculums. Second, although we have detailed information on child care in the year before kindergarten, we know less about experiences in earlier years, and therefore can not precisely model children's outcomes as a function of their cumulative experiences of preschool or center-based care.

The main conclusion of this analysis is that prekindergarten has few lasting positive effects on advantaged children's skills and persisting adverse effects on their behavior, but yields larger benefits for disadvantaged children. This suggests that the greatest return to public investments in early education may be obtained by using funds to increase disadvantaged children's enrollment in preschool and prekindergarten. Currently, most state funding initiatives do target at-risk children, but funding falls far short of providing all eligible children with access to these programs (Ripple et al., 1999). Additional expenditures to increase disadvantaged children's early education experiences are likely to improve their academic skills at school entry. Additional research is needed to determine whether these benefits result in long-term improvements in human capital. 


\section{References}

Alexander, Karl, Doris R. Entwisle, and Susan L. Dauber. 1993. "First Grade Classroom Behavior: Its Short- and Long-term Consequences for School Performance." Child Development, 64, 801-814.

Bainbridge, Jay, Marcia Meyers, SakikoTanako, and Jane Waldfogel. 2002. "Who is Getting Early Education? Family Income and the Gaps in Enrollment of 3- to 5-year-olds from 1968-2000." Mimeo, Columbia University School of Social Work.

Barnett, W. Steven. 1995. "Long-term Effects of Early Childhood Programs on Cognitive and School Outcomes." The Future of Children, 5, 25-5.

Bates, John E., Denny Marvinney, Timothy Kelly, Kenneth A. Dodge, David S. Bennett, and Gregory S. Pettit. "Child Care History and Kindergarten Adjustment." Developmental Psychology, 30, 690-700.

Belsky, Jay. 2001. "Emanuel Miller Lecture: Developmental Risks (Still) Associated with Early Child Care.” Journal of Child Psychology \& Psychiatry \& Allied Disciplines, 42, 845859.

Blank, Helen, Karen Schulman, and Danielle Ewen. 1999. Key Facts: Essential Information about Child Care, Early Education, and School-age Care. Washington, DC: Children's Defense Fund.

Blau, David. 2001. The Child Care Problem. NY, NY: Russell Sage Foundation.

Bowman, Barbara T., M. Suzanne Donovan, and M. Susan Burns, Eds. 2001. Eager toLearn: Educating our Preschoolers. Washington, DC: National Academy Press.

Bound, J., David A. Jaeger, and Regina Baker. 1995. "Problems with Instrumental Variables Estimation when the Correlation Between the Instruments and the Endogeneous Explanatory Variable is Weak." Journal of the American Statistical Association, 90, 443450.

Bradley, Robert H., Margaret Burchinal, and Patrick H. Casey. 2001. "Early Intervention: The Moderating Role of the Home Environment." Applied Developmental Science, 5, 2-8.

Bradley, Robert H., Robert F. Corwyn, Harriet P. McAdoo, and Cynthia Garcia Coll, 2001. "The Home Environments of Children in the United States Part I: Variations by Age, Ethnicity, and Poverty Status." Child Development, 72, 1844-1867.

Brooks-Gunn, Jeanne. 2000. "Do You Believe in Magic? What We Can Expect From Early Childhood Intervention Programs." Paper presented at a research briefing on "Early Childhood Intervention Programs: Are the Costs Justified?" sponsored by the Subcommittee of Human Resources of the U.S. House of Representatives Committee on Ways and Means and the Joint Center for Poverty Research, Washington DC, May 20.

Carneiro, Pedro and James J. Heckman. 2002. "Human Capital Policy.” Paper presented at the Alvin Hansen Seminar, Harvard University.

Caughy, Margaret O., Janet A. DiPietro, and Donna Strobino. 1994. "Day Care Participation as a Protective Factor in the Cognitive Development of Low-income Children." Child Development, 65, 457-471. 
Comittee for Economic Development. 2002. Preschool for All: Investing in a Productive and Just Society. New York: Committee for Economic Development.

Currie, Janet. In press.

Currie, Janet. 2000. “Early Childhood Intervention Programs: What Do We Know?” Paper presented at a research briefing on Early Childhood Intervention Programs: Are the Costs Justified? sponsored by the Subcommittee of Human Resources of the U.S. House of Representatives Committee on Ways and Means and the Joint Center for Poverty Research, Washington DC, May 20.

Currie, Janet, and Duncan Thomas. 1995. "Does Head Start Make a Difference?" American Economic Review, 85, 341-364.

Currie, Janet, and Duncan Thomas. 2000. "School Quality and the Longer-term Effects of Head Start." Journal of Human Resources, 35, 755-774.

Duncan, Greg, and Christina Gibson. 2000. "Selection and Attrition in the NICHD Child Care Study's Analyses of the Impacts of Child Care Quality on Child Outcomes." Mimeo, Northwestern University.

Education Commission of the United States. 2003. State funded Prekindergarten Programs. Retrieved December 19, 2003, from http://www.ecs.org/dbsearches/EarlyLearning_Reports.htm

Education Week. 2002. "Quality Counts 2002: Building Blocks for Success." Education Week, 2117, January 10. Retrieved on June 27, 2003 from, http://www.edweek.org/sreports/qc02/templates/article.cfm?slug=17exec.h21

Farran, Dale C. 2000. "Another decade of intervention for children who are low-income or disabled: What do we know now?" In Jack Shonkoff and Samuel Meisels (Eds)., Handbook of Early Childhood Intervention, Second edition (pp. 510-548). New York: Cambridge University Press.

Garces, Eliana, Duncan Thomas, and Janet Currie. 2002. "Longer-term Effects of Head Start." American Economic Review, 92, 999-1012.

Gilliam, William S. and Edward Zigler. 2001. "A Critical Meta-Analysis of All Evaluations of State-funded Preschool From 1977 to 1998: Implications for Policy, Service Delivery and Program Evaluation." Early Childhood Research Quarterly, 15, 441-473.

Gish, Melinda . 2002. Child Care: Funding and Spending Under Federal Block Grants. Washington, DC: Congressional Research Service, The Library of Congress.

Gresham, Frank M. and Stephen N. Eliot (1990). Elementary Scale A ("How Often?"). Circle Pines, MN: American Guidance Service, Inc.

Hinshaw, Stephen P. 1992. "Externalizing Behavior Problems and Academic Underachievement in Childhood and Adolescence: Causal Relationships and Underlying Mechanisms." Psychological Bulletin, 111, 127-125.

Hubbs-Tait, Laura, Anne M. Culp, Erron Huey, Rex Culp, Huei-Juang Starost and Charles Hare. 2002. "Relation of Head Start Attendance to Children's Cognitive and Social Outcomes: Moderation by Family Risk." Early Childhood Research Quarterly, 17, 539-558. 
Karoly, Lynn A., Peter W. Greenwood, Susan S. Everingham, Jill Houbé, M. Rebecca Kilburn, C. Peter Rydell, Mathew Sanders, and James Chiesa. 1998. Investing In Our Children: What We Do and Don't Know About the Costs and Benefits of Early Childhood Interventions. Santa Monica, CA: RAND.

Lewit, Eugene M., and Linda S. Baker. 1995. "School Readiness." The Future of Children, 2, 128-139.

Linver, Miriam R., Jeanne Brooks-Gunn., and Dafna E. Kohen. 2002. "Family Processes as Pathways from Income to Young Children's Development." Developmental Psychology, 5, 719-734.

Magnuson, Katherine A., Marcia Meyers, Christopher Ruhm, and Jane Waldfogel. (In press). "Inequality in Preschool Education and School Readiness." American Educational Research Journal.

Murphy, Kevin M., and Robert H. Topel. 1985. Estimation and Inference in Two-Step Econometric Models. Journal of Business \& Economic Statistics, 3, 370-379.

National Center for Education Statistics (2001). User's Manual for the ECLS-K Base Year Public-Use User's Manual. Washington, DC: U.S. Department of Education, Office of Educational Research and Improvement.

National Center for Education Statistics (2002). User's Manual for the ECLS-K First Grade Public Use Data Files and Electronic Code Book. Washington, DC: U.S. Department of Education, Office of Educational Research and Improvement.

NICHD Early Child Care Research Network. 2002a. "Child Care Structure> Process> Outcome: Direct and Indirect Effects of Child-Care Quality on Young Children's Development." Psychological Science, 13,199-206.

NICHD Early Child Care Research Network. 2003. "Does Amount of Time Spent in Child Care Predict Socioemotional Adjustment during the Transition to Kindergarten?" Child Development, 74, 976-1005.

NICHD Early Child Care Research Network. 2002b. “Early Child Care and Children's Development Prior to School Entry: Results from NICHD study of Early Child Care." American Educational Research Journal, 39, 133-164.

NICHD Early Child Care Research Network, and Greg Duncan. 2003. "Modeling the Impacts of Child Care Quality on Children's Preschool Cognitive Development." Child Development, 74, 1454-1475.

Peisner-Feinberg, Ellen S., Margaret R. Burchinal, Richard M. Clifford, Mary L. Culkin, Carollee Howes, Sharon Lynn Kagan, and Noreen Yazejian. 2001. "The Relation of Preschool Child-care Quality to Children's Cognitive and Social Development Trajectories Through Second Grade. Child Development, 723, 1534-1553.

Phillips, Deborah, Debra Mekos, Sandra Scarr, Kathleen McCartney, and Martha Abott-Shim. (2001). Within and Beyond the Classroom Door: Assessing Quality in Child Care Centers. Early Childhood Research Quarterly, 15, 475-496.

Ramey, Sharon L., and Craig T. Ramey. 2000. "The Effects of Early Childhood Experiences on Developmental Competence.” In Sheldon Danziger and Jane Waldfogel (Eds.) Securing 
the future: Investing in children from birth to college pp 122-150. New York: Russell Sage Foundation.

Rimm-Kaufman, Sara E., Robert C. Pianta, and Martha J. Cox. 2000. “Teachers' Judgements of Problems in the Transition to Kindergarten." Early Childhood Research Quarterly, 15, 147-166.

Ripple, Carol H., William S. Gilliam, Chanana, N., and Edward Zigler 1999. "Will Fifty Cooks Spoil the Broth?" American Psychologist, 54, 327-343.

Schweinhart, Lawrence J., Helen V. Barnes, and David Weikart. 1993. Significant Benefits: The High/Scope Perry Preschool Study Through Age 27. Ypsilanti, MI: High/Scope Press.

Schweinhart, Lawrence J., and David Weikart. 1997. "The High/Scope Preschool Curriculum Comparison Study Through Age 23." Early Childhood Research Quarterly, 12, 117-143,

Schulman, Karen, Helen Blank, and Danielle Ewen. 1999. Seeds of Success: State Prekindergarten Initiatives 1998-1999. Washington, DC: Children's Defense Fund.

Shonkoff, Jack P., and Deborah A. Phillips. Eds.2000. From Neurons to Neighborhoods: The Science of Early Childhood Development. Washington, DC: National Academy Press.

Smith, Timothy, Anne Kleiner, Basmat Parsad, Elizabeth Farris, and Bernard Green. 2003. Prekindergarten in U.S. Public Schools. U.S. Department of Education, National Center for Education Statistics: Washington, DC.

Stipek, Deborah J., Rachelle Feiler, Patricia Byler, Rosaleen Ryan, Sharon Milburn, and Julie M. Salmon. 1998. "Good Beginnings: What Difference Does the Program Make in Preparing Young Children for School?” Journal of Applied Developmental Psychology, 19, 41-66.

Takanishi, Ruby and Patrick H. DeLeon. 1994. "A Head Start for the $21^{\text {st }}$ Century." American Psychologist, 49, 120-122.

U.S. Bureau of the Census 1970. School Enrollment: Social and Economic Characteristics of Students, October 1969. Current population reports, P-20 Series. Washington, DC: U.S. Bureau of the Census.

US Census Bureau 2001. State estimates for people under age five in Poverty for US: 1998. Retrieved January 14, 2003 from http://www.census.gov/hhes/www/saipe/stcty/e98 00.htm

U.S. Department of Education, National Center for Education Statistics NCES. 2003. The condition of education. Washington, DC: U.S. Government Printing Office. Retrieved June 27, 2003, from http://nces.ed.gov/programs/coe/2002/pdf/01 2002.pdf

US General Accounting Office. 2000a. Preschool education: Federal investment for low-income children significant but effectiveness unclear. Washington, DC: United States General Accounting Office. Retrieved June 27, 2003, from, http://www.gao.gov/new.items/he00083t.pdf

US General Accounting Office. 2000b. Title I preschool education: More children served, but gauging the effect on school readiness difficult. Washington, DC: United States General Accounting Office. Retrieved June 27, 2003, from, http://www.gao.gov/new.items/he00171.pdf 
Vandell, Deborah L., and Barbara Wolfe. 2000. "Child Care Quality: Does It Matter and Does It Need to be Improved?" Institute for Research on Poverty Special Report, University of Wisconsin at Madison, November, 20.

Waldfogel, Jane. 2002. "Child Care, Women's Employment and Child Outcomes." Journal of Population Economics, 15, 527-548.

Wolfe, Barbara, and Scott Scrivner. 2003. "Providing Universal Preschool for Four-year olds." In Belle Sawhill (Ed.), One-percent for the Kids: New policies, brighter futures for America's children (pp. 113-135). Washington, DC: Brookings. 

Table 1: Selected Sample Characteristics, and Mean Child Outcomes, by Child CareArrangements in the Year Prior to Kindergarten

\begin{tabular}{|c|c|c|c|c|c|c|}
\hline Characteristic & All & $\begin{array}{c}\text { Parental } \\
\text { Care }\end{array}$ & $\begin{array}{l}\text { Other Non- } \\
\text { parental Care }\end{array}$ & $\begin{array}{l}\text { Head } \\
\text { Start }\end{array}$ & $\begin{array}{c}\text { Prekinder } \\
\text {-garten }\end{array}$ & Preschool \\
\hline \multicolumn{7}{|l|}{ Outcomes } \\
\hline \multicolumn{7}{|l|}{ Math Test Score } \\
\hline Fall Kindergarten & $\begin{array}{l}52.20 \\
(0.10)\end{array}$ & $\begin{array}{l}50.17 \\
(0.10)\end{array}$ & $\begin{array}{l}50.39 \\
(0.27)\end{array}$ & $\begin{array}{l}45.90 \\
(0.28)\end{array}$ & $\begin{array}{l}54.04 \\
(0.23)\end{array}$ & $\begin{array}{l}53.12 \\
(0.14)\end{array}$ \\
\hline Spring First Grade & $\begin{array}{l}51.97 \\
(0.09)\end{array}$ & $\begin{array}{l}50.93 \\
(0.10)\end{array}$ & $\begin{array}{l}50.89 \\
(0.26)\end{array}$ & $\begin{array}{l}46.63 \\
(0.32)\end{array}$ & $\begin{array}{l}53.28 \\
(0.21)\end{array}$ & $\begin{array}{l}53.18 \\
(0.12)\end{array}$ \\
\hline \multicolumn{7}{|l|}{ Reading Test Score } \\
\hline Fall Kindergarten & $\begin{array}{l}51.40 \\
(0.10)\end{array}$ & $\begin{array}{r}49.20 \\
(0.11)\end{array}$ & $\begin{array}{r}49.00 \\
(0.28)\end{array}$ & $\begin{array}{l}45.25 \\
(0.26)\end{array}$ & $\begin{array}{l}54.16 \\
(0.24)\end{array}$ & $\begin{array}{l}53.98 \\
(0.14)\end{array}$ \\
\hline Spring First Grade & $\begin{array}{l}52.00 \\
(0.09)\end{array}$ & $\begin{array}{l}51.01 \\
(0.10)\end{array}$ & $\begin{array}{l}50.93 \\
(0.26)\end{array}$ & $\begin{array}{l}47.06 \\
(0.31)\end{array}$ & $\begin{array}{l}53.01 \\
(0.23)\end{array}$ & $\begin{array}{l}53.37 \\
(0.12)\end{array}$ \\
\hline \multicolumn{7}{|l|}{ Self Control Score } \\
\hline Fall Kindergarten & $\begin{array}{l}0.96 \\
(0.10)\end{array}$ & $\begin{array}{l}1.78 \\
(0.11)\end{array}$ & $\begin{array}{c}0.34 \\
(0.26)\end{array}$ & $\begin{array}{l}-1.70 \\
(0.33)\end{array}$ & $\begin{array}{l}0.44 \\
(0.25)\end{array}$ & $\begin{array}{l}1.25 \\
(0.15)\end{array}$ \\
\hline Spring First Grade & $\begin{array}{c}0.43 \\
(0.10)\end{array}$ & $\begin{array}{l}1.31 \\
(0.11)\end{array}$ & $\begin{array}{l}0.16 \\
(0.28)\end{array}$ & $\begin{array}{l}-2.72 \\
(0.35)\end{array}$ & $\begin{array}{l}0.00 \\
(0.25)\end{array}$ & $\begin{array}{l}0.78 \\
(0.15)\end{array}$ \\
\hline \multicolumn{7}{|c|}{ Externalizing Behavior Score } \\
\hline Fall Kindergarten & $\begin{array}{l}-0.64 \\
(0.10)\end{array}$ & $\begin{array}{l}-2.06 \\
(0.11)\end{array}$ & $\begin{array}{l}-2.07 \\
(0.28)\end{array}$ & $\begin{array}{l}1.29 \\
(0.33)\end{array}$ & $\begin{array}{l}0.39 \\
(0.25)\end{array}$ & $\begin{array}{l}-0.45 \\
(0.15)\end{array}$ \\
\hline Spring First Grade & $\begin{array}{l}-0.24 \\
(0.10)\end{array}$ & $\begin{array}{l}-1.66 \\
(0.11)\end{array}$ & $\begin{array}{l}-0.92 \\
(0.29)\end{array}$ & $\begin{array}{l}2.33 \\
(0.35)\end{array}$ & $\begin{array}{l}0.77 \\
(0.23)\end{array}$ & $\begin{array}{l}-0.55 \\
(0.13)\end{array}$ \\
\hline $\begin{array}{l}\text { Retained in } \\
\text { Kindergarten }\end{array}$ & $\begin{array}{l}3 \% \\
(0.18)\end{array}$ & $\begin{array}{l}4 \% \\
(0.49)\end{array}$ & $\begin{array}{c}5 \% \\
(0.62)\end{array}$ & $\begin{array}{l}4 \% \\
(0.64)\end{array}$ & $\begin{array}{l}2 \% \\
(0.37)\end{array}$ & $\begin{array}{c}3 \% \\
(0.24)\end{array}$ \\
\hline \multicolumn{7}{|c|}{ Demographic Characteristic } \\
\hline Black & $\begin{array}{l}13 \% \\
(0.34)\end{array}$ & $\begin{array}{l}10 \% \\
(0.77)\end{array}$ & $\begin{array}{l}13 \% \\
(0.93)\end{array}$ & $\begin{array}{l}38 \% \\
(1.56)\end{array}$ & $\begin{array}{l}18 \% \\
(0.96)\end{array}$ & $\begin{array}{l}8 \% \\
(0.40)\end{array}$ \\
\hline Hispanic & $\begin{array}{l}11 \% \\
(0.31)\end{array}$ & $\begin{array}{l}14 \% \\
(0.90)\end{array}$ & $\begin{array}{l}15 \% \\
(1.03)\end{array}$ & $\begin{array}{l}14 \% \\
(1.13)\end{array}$ & $\begin{array}{l}10 \% \\
(0.76)\end{array}$ & $\begin{array}{l}8 \% \\
(0.41)\end{array}$ \\
\hline Asian & $\begin{array}{l}4 \% \\
(0.20)\end{array}$ & $\begin{array}{l}4 \% \\
(0.48)\end{array}$ & $\begin{array}{l}5 \% \\
(0.63)\end{array}$ & $\begin{array}{l}2 \% \\
(0.48)\end{array}$ & $\begin{array}{l}3 \% \\
(0.43)\end{array}$ & $\begin{array}{l}4 \% \\
(0.31)\end{array}$ \\
\hline Boy & $\begin{array}{l}50 \% \\
(0.51)\end{array}$ & $\begin{array}{l}52 \% \\
(1.30)\end{array}$ & $\begin{array}{l}50 \% \\
(1.48)\end{array}$ & $\begin{array}{l}47 \% \\
(1.61)\end{array}$ & $\begin{array}{l}49 \% \\
(1.25)\end{array}$ & $\begin{array}{l}51 \% \\
(0.85)\end{array}$ \\
\hline Child Age & $\begin{array}{l}5.71 \\
(0.00)\end{array}$ & $\begin{array}{l}5.70 \\
(0.01)\end{array}$ & $\begin{array}{l}5.70 \\
(0.01)\end{array}$ & $\begin{array}{l}5.70 \\
(0.01)\end{array}$ & $\begin{array}{l}5.73 \\
(0.01)\end{array}$ & $\begin{array}{l}5.73 \\
(0.01)\end{array}$ \\
\hline Income-to-Needs & $\begin{array}{l}3.36 \\
(0.04)\end{array}$ & $\begin{array}{c}2.55 \\
(0.07)\end{array}$ & $\begin{array}{l}2.99 \\
(0.09)\end{array}$ & $\begin{array}{c}1.27 \\
(0.04)\end{array}$ & $\begin{array}{l}4.00 \\
(.103)\end{array}$ & $\begin{array}{l}3.92 \\
(.052)\end{array}$ \\
\hline
\end{tabular}

Notes: Data are for children in the ELCS-K study. Math and reading skills are standardized scores (mean $=50, \mathrm{sd}=10)$. Behavior outcomes are standardized scores $(\mathrm{mean}=0, \mathrm{sd}=10)$. See Appendix Table 1 for definitions of sample characteristics. 
Table 2: OLS Estimates of the Effects of Prekindergarten on Academic Outcomes and Classroom Behavior in the Fall of Kindergarten

\begin{tabular}{lcccccccc}
\hline & \multicolumn{4}{c}{ Reading } & \multicolumn{9}{c}{ Math } \\
& $(1)$ & $(2)$ & $(3)$ & $(4)$ & $(1)$ & $(2)$ & $(3)$ & $(4)$ \\
\hline Prekindergarten & $3.17^{* *}$ & $1.77^{* *}$ & $1.29^{* *}$ & $1.26^{* *}$ & $2.36^{* *}$ & $1.31^{* *}$ & $0.96^{* *}$ & $0.93^{* *}$ \\
& $(0.33)$ & $(0.25)$ & $(0.24)$ & $(0.24)$ & $(0.31)$ & $(0.23)$ & $(0.22)$ & $(0.22)$ \\
Demographics & & & & & & & & \\
Home \& Family Environment & & $\mathrm{X}$ & $\mathrm{X}$ & $\mathrm{X}$ & & $\mathrm{X}$ & $\mathrm{X}$ & $\mathrm{X}$ \\
Neighborhood \& State Characteristics & & & & $\mathrm{X}$ & & & $\mathrm{X}$ & $\mathrm{X}$ \\
\end{tabular}

\begin{tabular}{lccccccccc} 
R-squared & .01 & .28 & .35 & .35 & .01 & .30 & .36 & .36 \\
\hline & \multicolumn{4}{c}{ Self Control } & \multicolumn{4}{c}{ Externalizing } \\
& $(1)$ & $(2)$ & $(3)$ & $(4)$ & $(1)$ & $(2)$ & $(3)$ & $(4)$ \\
\hline Prekindergarten & -0.63 & $-0.83^{* *}$ & $-0.88^{* *}$ & $-0.91^{* *}$ & $1.24^{* *}$ & $1.21^{* *}$ & $1.21^{* *}$ & $1.23^{* *}$ \\
& $(0.32)$ & $(0.32)$ & $(0.31)$ & $(0.31)$ & $(0.29)$ & $(0.28)$ & $(0.28)$ & $(0.28)$
\end{tabular}

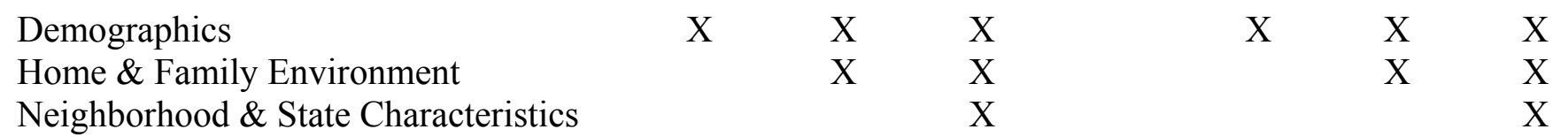

$\begin{array}{lllllllll}\text { R-squared } & .00 & .09 & .11 & .11 & .00 & .05 & .15 & .15\end{array}$

Notes: * p-value<.05; ** p-value<.01. The sample size for all analyses is 9,547. See Appendix Table 1 for details on the covariates. The coefficients represent the average difference between children in prekindergarten and those experiencing any other type of care in the year before kindergarten. Models have robust standard errors clustered at the school level. Dividing the coefficients by 10 gives effect sizes. 
Figure 1: State Prekindergarten Spending (per poor child under five years old) in 1998, by State

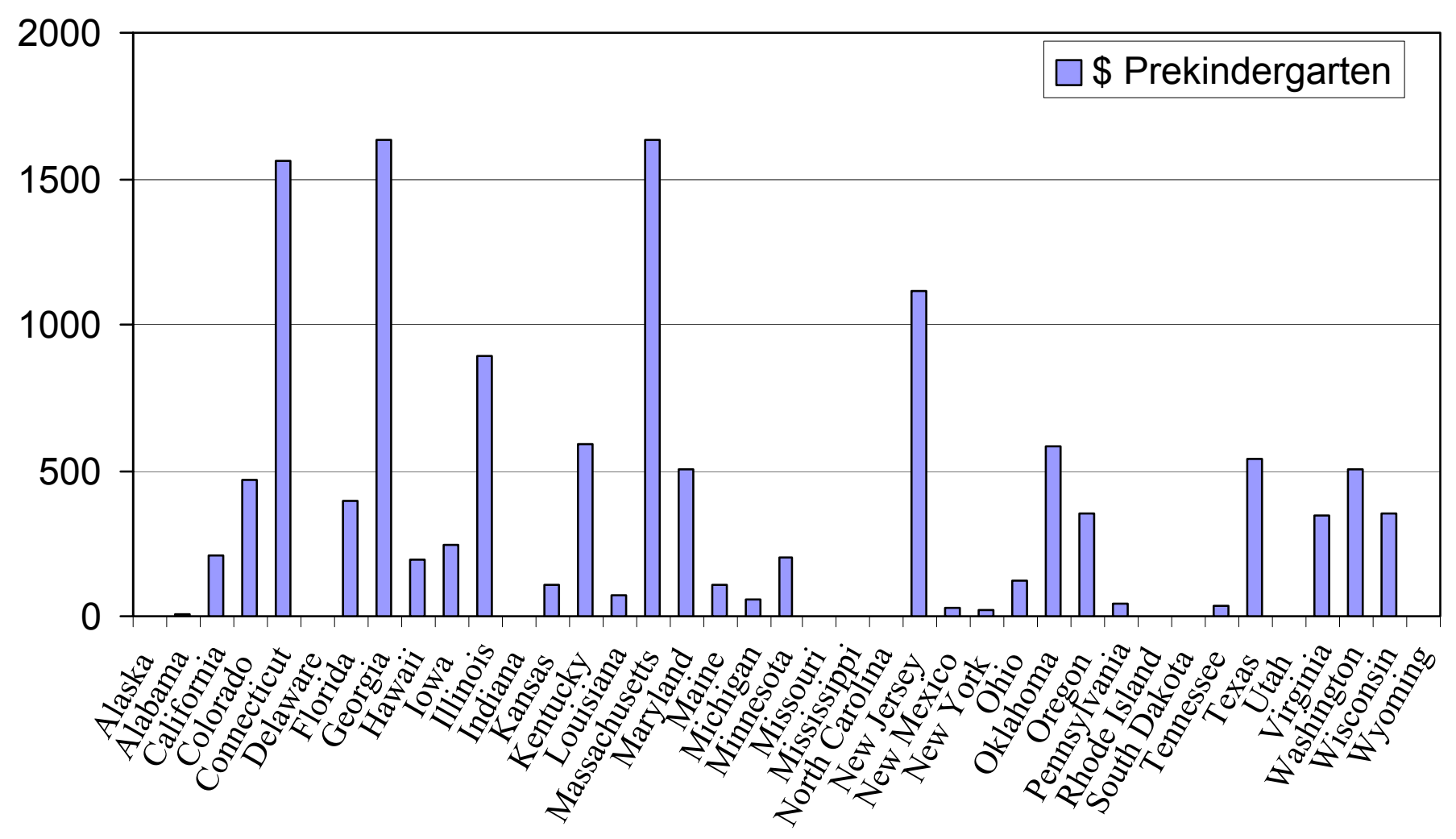



Table 3: IV and OLS Estimates of the Effect of Prekindergarten on Child Outcomes at Kindergarten Fall

\begin{tabular}{|c|c|c|c|c|}
\hline & Reading & Math & Self Control & Externalizing \\
\hline \multicolumn{5}{|c|}{ OLS Estimates } \\
\hline Prekindergarten & $\begin{array}{c}1.26^{* *} \\
(.24)\end{array}$ & $\begin{array}{l}.98^{* *} \\
(.22)\end{array}$ & $\begin{array}{c}-.84^{* *} \\
(.02)\end{array}$ & $\begin{array}{c}1.18^{* * *} \\
(.02)\end{array}$ \\
\hline Prekindergarten & $\begin{array}{l}7.26^{*} \\
(2.92)\end{array}$ & $\begin{array}{c}I V I \\
4.01 \\
(2.54)\end{array}$ & $\begin{array}{ll} & \\
& -3.51 \\
& (3.76)\end{array}$ & $\begin{array}{l}7.07 * \\
(3.12)\end{array}$ \\
\hline
\end{tabular}

\footnotetext{
Notes: ${ }^{*} \mathrm{p}$-value $<.05 ; * *$ p-value $<.01$. The sample size for all analyses is 9,547 . Models include the same covariates for child and family demographics, the home environment, neighborhood environment, and state characteristics as in model 4 of Table 2. Models have robust standard errors clustered at the school level. IV standard errors have also been correct for the two-stage estimation. The IV estimates instrument prekindergarten attendance by state spending on prekindergarten programs, as detailed in the text. See notes to Table 2. Dividing the coefficients by 10 gives effect sizes.
} 
Table 4: OLS Regressions for Child Outcomes in the fall of Kindergarten and Spring of the First Grade

\begin{tabular}{|c|c|c|c|c|c|}
\hline Year Before & Reading & Math & $\begin{array}{c}\text { Self } \\
\text { Control }\end{array}$ & Externalizing & $\begin{array}{l}\text { Held } \\
\text { Back }\end{array}$ \\
\hline & \multicolumn{5}{|c|}{ Kindergarten Fall } \\
\hline Prekindergarten & $\begin{array}{l}1.93 * * \\
(0.31)\end{array}$ & $\begin{array}{l}1.69 * * \\
(0.30)\end{array}$ & $\begin{array}{c}-1.25^{* *} \\
(0.40)\end{array}$ & $\begin{array}{l}1.91 * * \\
(0.36)\end{array}$ & -- \\
\hline Preschool & $\begin{array}{l}1.21 * * \\
(0.26)\end{array}$ & $\begin{array}{l}1.18^{* *} \\
(0.26)\end{array}$ & $\begin{array}{l}-0.62 \\
(0.32)\end{array}$ & $\begin{array}{l}1.27 * * \\
(0.29)\end{array}$ & -- \\
\hline Head Start & $\begin{array}{l}-0.52 \\
(0.34)\end{array}$ & $\begin{array}{l}-0.24 \\
(0.35)\end{array}$ & $\begin{array}{l}-0.87 \\
(0.47)\end{array}$ & $\begin{array}{l}0.99 * \\
(0.43)\end{array}$ & -- \\
\hline $\begin{array}{l}\text { Other Non- } \\
\text { Parental }\end{array}$ & $\begin{array}{l}-0.11 \\
(0.32)\end{array}$ & $\begin{array}{c}0.48 \\
(0.32) \\
\end{array}$ & $\begin{array}{c}0.78 \\
(0.41) \\
\end{array}$ & $\begin{array}{c}-1.20 * * \\
(0.38)\end{array}$ & -- \\
\hline Prekindergarten & $\begin{array}{c}0.37 \\
(0.29)\end{array}$ & $\begin{array}{c}0.48 \\
(0.28)\end{array}$ & $\begin{array}{c}\text { First Graa } \\
-1.43^{* *} \\
(0.40)\end{array}$ & $\begin{array}{l}\text { pring } \\
\qquad \begin{array}{l}2.28 * * \\
(0.38)\end{array}\end{array}$ & $\begin{array}{l}-0.51 \\
(0.71)\end{array}$ \\
\hline Preschool & $\begin{array}{c}0.18 \\
(0.24)\end{array}$ & $\begin{array}{c}0.44 \\
(0.23)\end{array}$ & $\begin{array}{c}-0.89 * * \\
(0.31)\end{array}$ & $\begin{array}{l}1.29 * * \\
(0.30)\end{array}$ & $\begin{array}{l}-0.62 \\
(0.57)\end{array}$ \\
\hline Head Start & $\begin{array}{l}-0.56 \\
(0.38)\end{array}$ & $\begin{array}{l}-0.50 \\
(0.38)\end{array}$ & $\begin{array}{c}-1.27 * * \\
(0.48)\end{array}$ & $\begin{array}{l}1.19^{* *} \\
(0.43)\end{array}$ & $\begin{array}{l}-1.02 \\
(0.87)\end{array}$ \\
\hline $\begin{array}{l}\text { Other Non- } \\
\text { Parental }\end{array}$ & $\begin{array}{l}-0.03 \\
(0.31)\end{array}$ & $\begin{array}{c}0.24 \\
(0.31)\end{array}$ & $\begin{array}{c}0.61 \\
(0.39)\end{array}$ & $\begin{array}{l}-0.37 \\
(0.37)\end{array}$ & $\begin{array}{r}0.77 \\
(0.91)\end{array}$ \\
\hline
\end{tabular}

Notes: * p-value $<.05 ; * *$ p-value $<.01$. See notes on Tables 2 and 3 . All models include the full set of covariates, corresponding to (model 4, Table 2). "Held Back" is a dichotomous variable set to 100 (zero) for individuals who are retained in kindergarten. . 
Table 5: OLS Estimates for Children in Low Instruction Classrooms

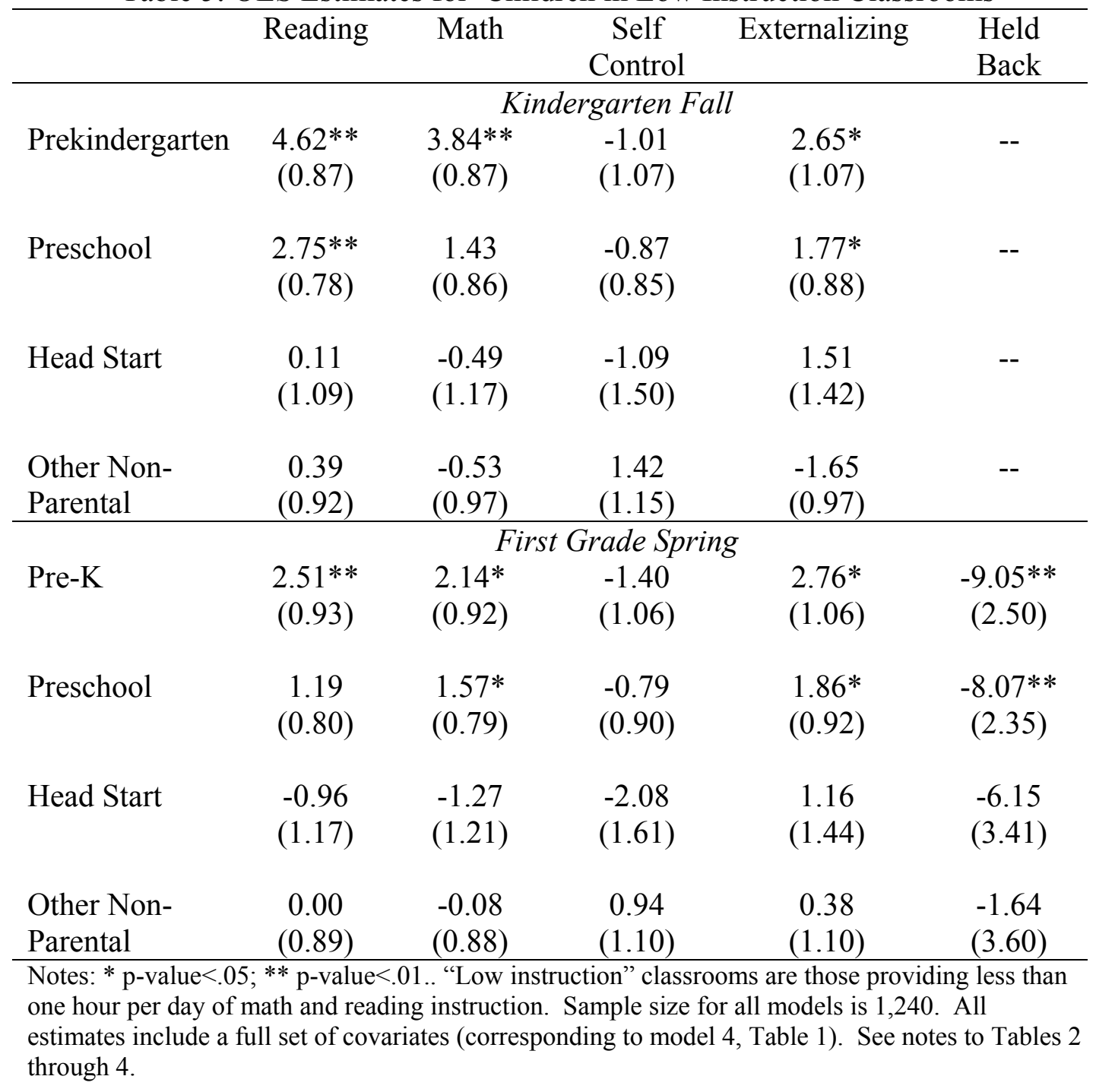


Table 6: OLS Estimates for Disadvantaged Children

\begin{tabular}{|c|c|c|c|c|c|c|c|c|c|c|}
\hline \multicolumn{6}{|c|}{ Children of Parents with Low Education or in Poverty $(\mathrm{N}=2083)$} & \multicolumn{5}{|c|}{ Children of Welfare Recipients $(\mathrm{N}=911)$} \\
\hline & Reading & Math & $\begin{array}{c}\text { Self } \\
\text { Control }\end{array}$ & Externalizing & $\begin{array}{l}\text { Held } \\
\text { Back }\end{array}$ & Reading & Math & $\begin{array}{c}\text { Self } \\
\text { Control }\end{array}$ & Externalizing & $\begin{array}{l}\text { Held } \\
\text { Back }\end{array}$ \\
\hline Prekindergarten & $\begin{array}{c}2.77 * * \\
(0.65)\end{array}$ & $\begin{array}{r}\text { Kin } \\
2.30^{* *} \\
(0.63)\end{array}$ & $\begin{array}{c}\text { garten } 1 \\
-1.74^{*} \\
(0.81)\end{array}$ & $\begin{array}{c}2.46^{* *} \\
(0.82)\end{array}$ & -- & $\begin{array}{c}2.78 * * \\
(1.00)\end{array}$ & $\begin{array}{l}\text { Kinde } \\
1.91^{*} \\
(0.93)\end{array}$ & $\begin{array}{c}\text { arten Fal } \\
-1.93 \\
(1.24)\end{array}$ & $\begin{array}{c}1.47 \\
(1.45)\end{array}$ & -- \\
\hline Preschool & $\begin{array}{c}1.66^{* *} \\
(0.52)\end{array}$ & $\begin{array}{l}1.97 * * \\
(0.54)\end{array}$ & $\begin{array}{l}-1.47 * \\
(0.69)\end{array}$ & $\begin{array}{c}1.99 * * \\
(0.65)\end{array}$ & -- & $\begin{array}{c}2.00 * * \\
(0.77)\end{array}$ & $\begin{array}{l}1.71 * \\
(0.82)\end{array}$ & $\begin{array}{c}-0.57 \\
(0.99)\end{array}$ & $\begin{array}{l}-0.27 \\
(1.13)\end{array}$ & -- \\
\hline Head Start & $\begin{array}{c}0.34 \\
(0.51)\end{array}$ & $\begin{array}{l}1.09 * \\
(0.55)\end{array}$ & $\begin{array}{l}-1.68 * \\
(0.69)\end{array}$ & $\begin{array}{l}1.53 * \\
(0.64)\end{array}$ & -- & $\begin{array}{c}0.73 \\
(0.76)\end{array}$ & $\begin{array}{c}0.47 \\
(0.78)\end{array}$ & $\begin{array}{l}-1.26 \\
(1.02)\end{array}$ & $\begin{array}{l}-0.59 \\
(1.17)\end{array}$ & -- \\
\hline $\begin{array}{l}\text { Other Non- } \\
\text { Parental }\end{array}$ & $\begin{array}{c}0.61 \\
(0.59)\end{array}$ & $\begin{array}{c}0.99 \\
(0.64)\end{array}$ & $\begin{array}{c}0.64 \\
(0.81)\end{array}$ & $\begin{array}{l}-1.03 \\
(0.75)\end{array}$ & -- & $\begin{array}{c}0.26 \\
(0.92)\end{array}$ & $\begin{array}{c}0.41 \\
(0.92)\end{array}$ & $\begin{array}{c}0.17 \\
(1.35)\end{array}$ & $\begin{array}{l}-0.70 \\
(1.29)\end{array}$ & -- \\
\hline Preschool & $\begin{array}{c}0.27 \\
(0.59)\end{array}$ & $\begin{array}{c}0.86 \\
(0.54)\end{array}$ & $\begin{array}{l}-1.21 \\
(0.68)\end{array}$ & $\begin{array}{c}2.25 * * \\
(0.66)\end{array}$ & $\begin{array}{l}-1.14 \\
(1.18)\end{array}$ & $\begin{array}{c}0.46 \\
(0.97)\end{array}$ & $\begin{array}{c}1.30 \\
(0.98)\end{array}$ & $\begin{array}{c}-0.65 \\
(1.10)\end{array}$ & $\begin{array}{c}0.44 \\
(1.11)\end{array}$ & $\begin{array}{c}-4.08+ \\
(2.40)\end{array}$ \\
\hline Head Start & $\begin{array}{l}-0.22 \\
(0.64)\end{array}$ & $\begin{array}{c}0.46 \\
(0.59)\end{array}$ & $\begin{array}{l}-1.02 \\
(0.71)\end{array}$ & $\begin{array}{l}1.72 * \\
(0.69)\end{array}$ & $\begin{array}{c}0.01 \\
(1.65)\end{array}$ & $\begin{array}{l}-0.56 \\
(1.01)\end{array}$ & $\begin{array}{c}0.32 \\
(0.97)\end{array}$ & $\begin{array}{c}-0.38 \\
(1.07)\end{array}$ & $\begin{array}{c}0.55 \\
(1.16)\end{array}$ & $\begin{array}{l}-3.12 \\
(2.73)\end{array}$ \\
\hline $\begin{array}{l}\text { Other Non- } \\
\text { Parental }\end{array}$ & $\begin{array}{c}0.57 \\
(0.64)\end{array}$ & $\begin{array}{c}1.02 \\
(0.65)\end{array}$ & $\begin{array}{c}0.71 \\
(0.75)\end{array}$ & $\begin{array}{c}0.37 \\
(0.75)\end{array}$ & $\begin{array}{l}2.67 \\
(2.13)\end{array}$ & $\begin{array}{l}-0.16 \\
(1.10)\end{array}$ & $\begin{array}{c}0.77 \\
(1.15)\end{array}$ & $\begin{array}{l}1.36 \\
(1.27)\end{array}$ & $\begin{array}{c}0.18 \\
(1.48)\end{array}$ & $\begin{array}{l}2.21 \\
(3.96)\end{array}$ \\
\hline
\end{tabular}


Appendix Table 1: Definitions, Additional Details, and Notes about Covariates Used in Analyses

\begin{tabular}{|c|c|}
\hline Constructs and Variables & Definition, Details, and Notes \\
\hline & Demographic Characteristics \\
\hline \multicolumn{2}{|l|}{ Child characteristics } \\
\hline Child age & Continuous variable. Child age in months (specific to timing of assessment). \\
\hline Child gender & Dummy variable \\
\hline Birth weight & 2 dummy variables for: $<1500$ grams, $1500-2500$ grams. \\
\hline Child weight & Average of two interviewer assessed measurements in lbs. \\
\hline Child height & Average of two interviewer assessed measurements in inches. \\
\hline Race and ethnicity & Black, Hispanic, Native American, Asian. (4 dummy variables). \\
\hline \multicolumn{2}{|c|}{ Parental reports of family characteristics } \\
\hline \# of children in household & Ordinal variable. Ranges from 1 to 11. \\
\hline Family structure & $\begin{array}{l}\text { Single parent (one biological parent), blended family (one biological and one } \\
\text { non-biological parent), adopted or foster parents ( } 3 \text { dummy variables). }\end{array}$ \\
\hline City vs. Rural residency & Locality is city or town (2 dummy variables). \\
\hline Region of country & North, South, Midwest (3 dummy variables). \\
\hline Early maternal employment & $\begin{array}{l}\text { Mother ever employed between child's birth and entry into kindergarten } \\
\text { (dummy variable). }\end{array}$ \\
\hline Father and mother's education & $\begin{array}{l}\text { Less than high school degree through advanced post-graduate degree (6 } \\
\text { dummy variables for each parent). }\end{array}$ \\
\hline English only spoken in home & Mother never vs. ever speaks foreign language to child (dummy variable). \\
\hline $\begin{array}{l}\text { Father's \& Mother's } \\
\text { employment status }\end{array}$ & $\begin{array}{l}\text { Full-time ( } 35 \text { or more hours per week), part-time work (fewer than } 35 \text { hours } \\
\text { per week), or no work ( } 2 \text { dummy variables for each parent). }\end{array}$ \\
\hline Use of WIC & $\begin{array}{l}\text { Mother or child ever participated in Women, Infants and Children nutritional } \\
\text { supplement program (dummy variable). }\end{array}$ \\
\hline \multirow[t]{2}{*}{$\begin{array}{l}\text { Household income-to-needs } \\
\quad \text { ratio }\end{array}$} & Household income vs. federal poverty level ( 9 dummy variables). \\
\hline & Home and Family Environment Variables \\
\hline \multicolumn{2}{|c|}{ Parental reports of educational expectations, kindergarten fall } \\
\hline Educational expectations & Parental Expectations for Child's education (4 dummy variables) \\
\hline Importance of skills & $\begin{array}{l}\text { Importance of skills: counting, sharing, communication, drawing, knowledge } \\
\text { of letters ( } 5 \text { variables) }\end{array}$ \\
\hline
\end{tabular}


Appendix Table 1 Continued

Parental reports of home learning activities, kindergarten fall

Choice of home location

Home learning activities

\# of children's books in home

\# of music tapes, CDs, or

records in home

Reading outside of school
Parents chose home location for current school (dummy variable).

Frequency of 7 activities: building things, teaching about nature, playing sports, doing art, doing chores, singing songs, playing games..

Ordinal variable. Ranges from 0 to 200 .

Ordinal variable. Ranges from 0 to 100 .

Frequency of child looking at picture books/reading outside of school (2 variables).

Family member school involvement, kindergarten fall

Attendance or participation in

Attendance since beginning of school year at PTA meetings, open houses, school activities parent groups, parent advisory meetings; volunteered at school, participated in school fundraiser (6 dummy variables).

Parental reports of parent-child relationship, kindergarten spring

Parenting stress and depression Two continuous variables (averages of 8 and 12 items). Higher scores composites indicate more stress, depression.

Spanking Parent spanked child in last week (dummy variable).

Parental reports of family routines, structured activities, and learning opportunities, kindergarten spring Eating Habits.

Days per week family usually eats meals together, at regular time (4 variables).

Family has computer Dummy variable.

T.V

Reading, visiting educational settings outside of school

Other non-school activities
Number of hours child watches TV on weekdays.

Frequency of child looking at picture books/reading outside of school, visiting zoo, library, museum, concert (6 variables).

Child has ever taken lessons or participated in performing arts or organized clubs outside of school (7 dummy variables).

Parental reports of neighborhood quality, kindergarten spring

Neighborhood quality composite Mean of 6 items asking about neighborhood problems. 